\title{
Corona, met de 'd' van dood
}

\author{
Martin J.M. Hoondert*
}

\begin{abstract}
Summary
In this article I explore the way people have dealt with death during the COVID-19 pandemic. Based on a file with newspaper articles, tweets, Facebook posts, books, online stories and interviews I trace cultural patterns or so-called death mentalities, with a focus on the situation in the Netherlands. The theoretical framework is based on both Ariès' and Jacobsen's characteristics of different ways of dealing with death. These cultural patterns concern both ideas and practices. A tentative conclusion is that on the one hand there is denial of death, on the other hand the ritual changes indicate a protest against death by corona.
\end{abstract}

\section{Inleiding}

Op het moment dat ik dit artikel schrijf (begin september 2021) zijn de voorspellingen en emoties ten aanzien van de COVID-19 pandemie in Nederland tegenstrijdig. Enerzijds heerst er een sterk sentiment tegen de coronamaatregelen en zijn velen geneigd het leven weer op te pakken alsof corona niet meer bestaat. Anderzijds leeft bij velen de vrees voor de opleving van corona in het najaar, veroorzaakt door onder meer het openstellen van het onderwijs en andere versoepelingen. Corona zorgt niet alleen voor een stevig maatschappelijk debat, zowel op straat en op de werkvloer als in de media, maar leidt ook tot nieuwe inzichten inzake werk, reizen, klimaat en afhankelijkheid in een globale economische orde. De vraag is of deze nieuwe inzichten ook leiden tot nieuwe culturele patronen.

Eén van de aspecten van de COVID-19 pandemie dat tot nu toe onbelicht is gebleven, betreft de omgang met de dood. Volgens het RIVM zijn er sinds het uitbreken van corona in Nederland ruim 18.000 personen door toedoen van het virus overleden. ${ }^{1}$ Het CBS meldt een groter aantal sterfgevallen door corona: alleen al in 2020 stierven 20.000 personen aan de gevolgen van het coronavirus. ${ }^{2}$ De aanwezigheid van de dood in de samenleving werd zichtbaar in de iconische beelden van mensen op de Intensive Care, vaak op hun buik

* Martin Hoondert is universitair hoofddocent 'Ritual Studies' aan de Universiteit van Tilburg. 
en aan de beademing, de rijen met doodskisten in het Italiaanse Bergamo ${ }^{3}$ en de externe koelruimtes voor overledenen bij crematoria. ${ }^{4}$ Vele malen werd in het NOS Achtuurjournaal het aantal doden per dag genoemd. Veel van deze doden stierven, bijna in stilte, in de verpleeghuizen..$^{5}$ De vraag die ik in dit artikel wil verkennen is of de dominante aanwezigheid van de dood in de Nederlandse samenleving door toedoen van het coronavirus heeft geleid tot een andere omgang met de dood, tot een nieuw cultureel patroon. Deze vraag kwam in mij op na lezing van het prikkelende boekje De coronastorm. Hoe een virus ons verstand wegvaagde (2020) van de filosoof René ten Bos. Ten Bos analyseert de coronacrisis aan de hand van 26 alfabetisch geordende lemma's. Een dergelijke opzet vraagt om het maken van scherpe keuzes en Ten Bos koos ervoor onder de letter 'd' het lemma 'deskundigen' te behandelen en niet voor het door mij verwachte lemma 'dood'. Het ontbreken van dit lemma stimuleerde mij om er aandacht aan te besteden.

De vraag naar de manier waarop wij omgaan met de dood kent een lange geschiedenis. Het traceren van culturele patronen inzake de omgang met de dood werd geïnitieerd door de Franse historicus Philippe Ariès (1914-1984). Ik gebruik zijn werk als conceptueel kader voor mijn exploratief onderzoek naar de omgang met de dood in de Nederlandse cultuur in relatie tot de COVID-19 pandemie. Heel concreet is de vraagstelling: hoe wordt tijdens de coronacrisis in Nederland omgegaan met de dood, welke culturele patronen inzake de omgang met de dood zijn te traceren? Ik ga nu alvast zeggen dat ik deze vraag niet ten volle kan beantwoorden, simpelweg omdat de vraag naar een cultureel patroon pas te beantwoorden is als er voldoende afstand in de tijd is; aangezien we nog steeds leven in coronatijd, is de afstand te klein; we staan te dichtbij om het patroon (of: de patronen) goed te kunnen zien. Maar de coronaperiode heeft wel lang genoegd geduurd om de omtrekken van enkele patronen nu al te kunnen te signaleren.

De opzet van mijn artikel is als volgt: in de volgende paragraaf ga ik in op het werk van Ariès en de relevante literatuur die na zijn baanbrekende studies is verschenen. Vervolgens geef ik inzicht in de bronnen en wijze van analyseren van deze bronnen. Daarna presenteer ik de resultaten van mijn onderzoek. Tot slot kom ik tot een voorlopige conclusie. ${ }^{6}$ 


\section{Conceptueel kader: culturele patronen inzake de omgang met de dood}

De Franse historicus Philippe Ariès schreef diverse studies over concepten die enerzijds alledaags en vanzelfsprekend zijn, anderzijds in de loop van de tijd een andere betekenis hebben gekregen (en dus minder vanzelfsprekend zijn dan ze op het eerste gezicht lijken). Zo publiceerde hij over het kind, familie en de dood. Zijn eerste boek, eigenlijk een reeks van lezingen die hij had gehouden aan de John Hopkins University in de Verenigde Staten, was Western Attitudes toward Death from the Middel Ages to the Present (1974). Enkele jaren later verscheen het vuistdikke L'Homme devant la Mort (1977), in het Engels vertaald als The Hour of our Death (1981) en in het Nederlands onder de titel Het uur van onze dood. Duizend jaar sterven, begraven, rouwen en gedenken (1987). In zijn studies onderscheidt Ariès vier, later vijf, 'death mentalities'. Het gaat hierbij om houdingen ten opzichte van de dood die hun weerslag vinden in het denken en doen van mensen. Het concept 'death mentalities' verwijst dus niet alleen naar hoe mensen denken over de dood, maar ook hoe dit denken in hun handelen (bijvoorbeeld in uitvaartrituelen) en andere culturele expressies (zoals beeldende kunst of romans) gestalte krijgt. Denken en doen gaan hier samen op: het denken krijgt uitdrukking in het doen, maar andersom kan ook: het doen gaat vooraf aan het denken en is als zodanig performatief.

Deze mentaliteiten hebben zowel een individuele als collectieve dimensie, die, uiteraard, nauw samenhangen. Het gaat mij, in navolging van Ariès, om de collectieve houdingen ten opzichte van de dood, om patronen die in de culturele expressies te traceren zijn. Ariès zegt hierover, in 1974:

\footnotetext{
“(...) the attitude toward death may appear almost static over very long periods of time. It appears to be a-chronic. And yet, at certain moments, changes occur, usually slow and unnoticed changes, but sometimes, as today, more rapid and perceptible ones." (Ariès 1974, 1)
}

De Deense sociologen Michael Hviid Jacobsen en Anders Petersen stellen dat de omgang met de dood vanuit cultureel en sociologisch perspectief verandert door "changes in the way we live our lives and organize societies - due to developments in demography, science, technology, economy, values, norms, politics, beliefs, and ways of cohabitation" (Jacobsen \& Petersen 2020, 4). Juist hier dient zich de vraag aan: is de omgang met de dood onder invloed van corona veranderd door de impact van corona op de door Jacobsen en Petersen 
genoemde maatschappelijke dimensies? Ook Jacobsen en Petersen gaan in hun artikel in op deze vraag, niet op basis van helder omschreven bronnen en empirisch onderzoek, maar als reflectieve reactie op wat er in grote lijnen gaande is in met name Europa in de eerste maanden van de coronacrisis (maart-mei 2020).

De eventuele veranderingen in de omgang met de dood worden het beste zichtbaar in vergelijking met eerdere culturele patronen of 'death mentalities'. Hiervoor is juist het werk van Ariès en de hiervoor genoemde Jacobsen heel bruikbaar. Ariès onderscheidt vier culturele patronen, Jacobsen voegde er een vijfde aan toe. Ik beschrijf ze kort en bondig en kom er in de laatste sectie van dit artikel op terug als vergelijkingsmateriaal voor de omgang met de dood onder invloed van de COVID-19 pandemie.

In zijn geschiedenis van de omgang met de dood ziet Ariès een scherpe cesuur in de $18^{\mathrm{e}}-19^{\mathrm{e}}$ eeuw. Daarvoor is de dood een vanzelfsprekend gegeven, vanaf de $18^{\mathrm{e}}-19^{\mathrm{e}}$ eeuw wordt de dood gezien als een 'drama' en in toenemende mate niet geaccepteerd, ontkend en tot taboe verklaard. In de eerste periode - Ariès begint zijn geschiedenis in de vroege middeleeuwen - onderscheidt hij twee culturele patronen (Ariès 1974, 2-52; 1987, 13-306). Het eerste patroon typeert hij als 'tamed death': de dood, of wellicht beter: de angst voor de dood wordt 'getemd' door een vanzelfsprekende rituele omgang met sterven en dood. In dit patroon tekent zich in de $12^{\mathrm{e}}-13^{\mathrm{e}}$ eeuw een subtiele maar belangrijke verandering af. De rituele vormen blijven gehandhaafd, maar in het denken over de dood komt de nadruk sterk te liggen op het individu in relatie tot het Laatste Oordeel. Ariès typeert dit patroon als 'my death'. Het wordt onder meer zichtbaar in het Dies Irae, een gezang dat in deze periode aan de Requiem mis wordt toegevoegd en waarin een ik-figuur smeekt en bidt om redding en genade (Hoondert 2012). Langzaam maar zeker verschuift de aandacht van het stervensuur en de daarbij horende ritualiteit naar een steeds aanwezig besef van sterfelijkheid: levenskunst en stervenskunst raken nauw met elkaar verweven.

Vanaf de $18^{\mathrm{e}}$ eeuw krijgt de dood een nieuwe betekenis, nieuwe culturele patronen tekenen zich af. Onder meer door de ontwikkeling van het kerngezin wordt de dood van een direct naaste ervaren als een drama, het gemis als ondraaglijk. Niet alleen wordt de dood minder als een vanzelfsprekend gegeven beschouwd, ook valt het accent nu meer op de dood van de ander dan op de eigen dood. Ariès typeert dit patroon met de titel 'your death'. Het sterven van de ander wordt ervaren als een breuk, Ariès spreekt van een "intolerance of separation" (Ariès 1974, 59). Dit leidt tot een uitgebreide 
herdenkingscultuur, met begraafplaatsen als parkachtige landschappen waar de levenden bij de doden kunnen vertoeven.

Een grote verandering vindt plaats in de $20^{\mathrm{e}}$ eeuw. Langzaam maar zeker verdwijnt de dood uit het openbare leven. Mensen sterven niet meer thuis, maar in het ziekenhuis. Het sterven is de slotfase van een ziekbed, als medisch ingrijpen geen zin meer heeft (Zie ook Becker 1973). Ariès duidt deze 'death mentality' aan als de 'invisible death', ook wel de 'forbidden death' en spreekt van een 'leugen' die de 'dood tot een taboe maakt. De doodzieke mens en diens omgeving spelen samen de komedie van 'er is niets veranderd', 'het leven gaat gewoon door' en 'alles is nog mogelijk'” (Ariès 1987, 587). Jacobsen en Petersen verbinden dit nieuwe culturele patroon inzake omgang met de dood met het modernisme:

\footnotetext{
"Death was incompatible with modern society, modern medicine, the modern way of life, and with all its promises and beliefs in its own superiority. Death - and not least the failure to defeat it - was seen as a 'scandal of reason' and an insult to the rationality of modern science trying to control every single aspect of human and social life." (Jacobsen \& Petersen 2020, 7)
}

Het taboe op de dood leidt zowel tot een professionalisering van alles wat met sterven en dood te maken heeft, als een verandering in ritualiteit. Sterven en dood, van het ziekbed tot en met de begrafenis, worden in handen gelegd van professionals: artsen en uitvaartondernemers. Uitvaartrituelen versoberen en worden zakelijker, we zien in deze periode de opkomst van het crematorium met een zakelijk, kort ritueel (Nijland, Overtoom \& Hoondert 2017). Tekenen van openbare rouw, bijvoorbeeld zichtbaar in de kleding van de rouwenden, verdwijnen uit het straatbeeld.

Jacobsen voegt een vijfde 'death mentality' toe, voortbouwend op het werk van Ariès. Dit culturele patroon ziet hij opkomen aan het eind van de $20^{\mathrm{e}}$ - begin van de $21^{\mathrm{e}}$ eeuw en duidt hij aan als 'spectacular death' (Jacobsen 2016). Jacobsen ziet continuïteit vanuit de voorgaande periode, met name de aspecten van medicalisering en de pogingen de dood onder controle te krijgen, maar het etiket 'verboden of onzichtbare dood' en het taboe op de dood kloppen niet meer met de wijze waarop mensen in de $21^{\mathrm{e}}$ eeuw omgaan met de dood. Jacobsen typeert de dood als een 'spectacle': "It is something that we witness at a safe distance but hardly ever experience upfront" (Jacobsen 2016, 10). De dood is alomtegenwoordig in onze cultuur, met name door aandacht voor de dood in de media, maar in ons persoonlijk leven blijft de dood op afstand. Dit heeft ook impact op de ritualiteit rondom de dood. Sinds de late 
$20^{\mathrm{e}}$ eeuw worden de uitvaartrituelen uitgebreider: het korte ritueel van 20 tot 30 minuten, afgesloten met koffie en cake komt steeds minder voor. Er is sprake van toenemende ritualiteit, inclusief uitgebreide catering bij de condoleance (Venbrux, Heessels \& Bolt 2008; Venbrux, Peelen \& Altena 2009). Dit wordt ook zichtbaar in de opkomst van een nieuw beroep: de ritueelbegeleider (Embsen \& Overtoom 2007; 2017). Wat echter opvalt bij deze re-ritualisering van de dood is dat niet zozeer de dood zelf ter sprake komt, maar het geleefde leven. Ook hier wordt de dood op veilige afstand gehouden door eerst en vooral het leven 'te vieren' (Wojtkowiak 2012).

De vijf beschreven culturele patronen inzake omgang met de dood zie ik eerst en vooral als een hulpmiddel om na te denken over de dood. In tegenstelling tot Ariès en Jacobsen, die de culturele patronen op een tijdlijn plaatsen, zie ik naast veranderende culturele patronen inzake de omgang met de dood ook continuiteit en gelijktijdigheid van deze culturele patronen. Mijn these is dat de genoemde culturele patronen, of in elk geval elementen daarvan, voortbestaan, zowel op het niveau van het denken als van het doen. Ook nu nog is er sprake van de 'getemde dood', bijvoorbeeld in kerkelijke uitvaartrituelen. En in de herdenkingscultuur rondom individuele doden is de 'your death' mentaliteit zichtbaar. Ik gebruik de 'death mentalities' als heuristisch en hermeneutisch hulpmiddel: ze helpen mij om ontwikkelingen inzake de omgang met de dood op het spoor te komen en te begrijpen.

\section{Bronnen en analyse}

\section{Bronnen}

Voor het empirisch onderzoek naar de omgang met de dood in tijden van corona sluit ik aan bij de benadering die ook Ariès hanteerde. Hij staat een explorerende, enigszins subjectieve en intuitieve aanpak voor: "The observer scans a chaotic mass of documents and tries to decipher, beyond the intentions of the writers or artists, the unconscious expression of the sensibility of the age" (Ariès 1983, xiii). Vanaf het begin van de coronacrisis in Nederland, maart 2020, ben ik een dossier gaan aanleggen, bestaande uit nieuwsberichten en reportages uit kranten en tijdschriften, online artikelen, opiniestukken, tweets en berichten op Facebook. De meeste items in mijn dossier betreffen de Nederlandse situatie, maar in het dossier zitten ook opinieartikelen die ingaan op onder meer de situatie in Italië en Engeland.7 Een tweede onderdeel van het dossier vormen enkele boeken die expliciet ingaan op de 
coronacrisis. Ik noem het al eerder genoemde boek van René ten Bos en vul aan met Pfeijffers Dagboek in tijden van besmetting (Pfeijffer 2020), CoronA tot $Z$ van Jim Jansen en Dolf Jansen (Jansen \& Jansen 2020), De kracht van samen van Hella van der Wijst over het begin van de coronacrisis in Oost-Brabant (Wijst 2020), en Coronakronieken van Daan Heerma van Voss (Heerma van Voss 2020). Een derde onderdeel van het dossier zijn de ervaringsverhalen die in het kader van het onderzoeksproject 'Uitvaarten in tijden van corona' verzameld zijn. Dit betreft een onderzoeksproject van de Funeraire Academie dat in november 2020 is gestart met een webinar en dat doorloopt tot oktober 2021. Professionals, nabestaanden en andere betrokkenen kunnen verhalen uploaden op een website, een zogenoemde 'Verhalenmuur'. Deze verhalen heb ik betrokken in mijn onderzoek. Een vierde onderdeel van het dossier betreft tien interviews die ik in het kader van het hierboven genoemde onderzoeksproject van de Funeraire Academie heb gehouden met professionals in het werk- en onderzoeksveld van sterven en dood. ${ }^{8}$

\section{Analyse}

Naast het verzamelen van bronnen, als eerste stap naar een beantwoording van de onderzoeksvraag, is het mijn taak als onderzoeker om datgene wat $\mathrm{ik}$ in de bronnen lees op een geordende wijze te presenteren. De ordening is stap twee in het proces van onderzoek doen en is gebaseerd op een analyse van het materiaal. Deze analyse heb ik gedaan door middel van twee cycli van coderen: 1. initial coding waarbij ik dicht op de bronnen kernwoorden (codes) toeken aan de afzonderlijke, inhoudelijk af te kaderen fragmenten; 2. axial coding waarbij ik de codes uit de eerste cyclus heb geclusterd in inhoudelijk coherente categorieën (Saldaña 2021). Deze inhoudelijke clustering heb ik uiteraard gedaan met het oog op de vraagstelling van mijn onderzoek naar veranderende culturele patronen inzake omgang met de dood. Axial coding is dus niet alleen ordening van de gegevens, maar ook een interpretatieve stap. De geordende presentatie van hetgeen ik gevonden heb in de bronnen, zoals weergegeven in de volgende sectie van dit artikel, is het resultaat van deze twee cycli van coderen.

\section{Resultaten: omgang met de dood in Nederland in coronatijd}

In het nu volgende presenteer ik de gegevens van mijn corona-dossier aan de hand van de categorieën die zijn voortgekomen uit het proces van coderen. 


\section{Tijd}

Een belangrijke dimensie van omgaan met de dood is tijd. Met name in de eerste golf van de coronacrisis (maart-juni 2020) kwam de dood door toedoen van corona vaak onverwacht. Mensen werden, vaak in haast, opgenomen op de Intensive Care afdeling, in coma gebracht en aan de beademing gelegd. Contact met de zieke was vaak niet mogelijk, ook omdat de ziekenhuizen het bezoek aan de IC afdelingen sterk beperkten. Mensen stierven vaak zonder hun direct dierbaren om hen heen. Dit leidde ertoe dat 'laatste woorden' niet meer gezegd konden worden en dat er geen tijd en ruimte was voor verzoening. “De mogelijkheid om 'in het reine te komen' met elkaar is er nu tijdens de coronacrisis niet altijd. Losse eindjes kunnen niet meer afgehecht worden, wat tot jarenlange schuldgevoelens en verdriet kan leiden." 9

Tijd speelde ook een rol in het plannen van een uitvaart of crematie. Bij sommige crematoria was het in de eerste golf zo druk, dat families lang moesten wachten voor een crematieplechtigheid mogelijk was. In Noord-Brabant werden eind maart 2020 crematies ingepland op zondagen en in de avonduren. ${ }^{10}$ Het actualiteitprogramma Nieuwsuur berichtte op 28 maart 2020 op Twitter: "Brabanders leven deze weken op het ritme van de uitvaarten. De ene na de andere. Sommige uitvaartondernemers hebben het zo druk dat ze nee moeten verkopen." ${ }^{11}$ In de documentaire Zesendertig vertellen medewerkers van uitvaartcoöperatie DELA wat de impact van corona was op hun werk. Eén van de medewerkers vertelt dat corona heel plotseling 'binnenkwam', eerst nog voorzichtig, maar vervolgens met een piek aan overledenen. Op een gegeven moment lagen er 36 overledenen in de koelruimtes van het crematorium, een ongekend hoog aantal. ${ }^{12}$

Ook bij het opbaren van mensen die overleden waren aan corona was tijd een belangrijke factor. In het begin van de coronacrisis was niet duidelijk of het virus besmettelijk blijft in een dood lichaam. Om die reden moesten overledenen 48 uur gekoeld blijven en mocht er niemand bij. Pas daarna mochten zij thuis of elders opgebaard worden (Wijst 2020, 94). Bij het condoleancebezoek in de dagen voorafgaand aan de uitvaart moest er goed gepland worden om te voorkomen dat er te veel mensen tegelijk om de baar stonden. Dit heeft ook een voordeel, zoals blijkt uit het verhaal dat Hella van der Wijst vertelt over het overlijden van Toos en de wijze waarop haar twee dochters Femke en Baukje het afscheid vorm gaven:

"Thuis opbaren mag niet en afscheid nemen van Toos in het rouwcentrum is lastig met alle coronarichtlijnen. Maar door goede afspraken (...) zetten Baukje en Femke een schema op waarbij familie en vrienden die willen en durven toch 
afscheid kunnen nemen. Iedereen wacht in de auto tot hij of zij aan de beurt is. Misschien is afscheid nemen op deze manier wel intenser en persoonlijker dan wanneer iedereen tegelijk komt en je voor niemand eigenlijk tijd hebt." (Wijst 2020, 146-147)

\section{Plaats}

Het grote aantal doden onder invloed van COVID-19 leidde ook tot een gebrek aan plaats. In Brazilië, New York en andere plaatsen in de wereld werden massagraven aangelegd om het grote aantal doden te kunnen begraven. ${ }^{13}$ Zover kwam het in Nederland niet, maar de dimensie 'plaats' speelde wel op diverse fronten. Ten eerste konden mensen soms niet sterven op de door hen of door de naaste familie gewenste plek, maar stierven in het ziekenhuis of verpleeghuis, zonder de mogelijkheid nog naar huis overgebracht te worden. Ten tweede konden veel mensen de uitvaart van een familielid, vriend of bekende niet bijwonen vanwege het beperkt aantal personen dat bij een uitvaart aanwezig mocht zijn (variërend van 30 tot 100). Mensen moesten noodgedwongen de uitvaart thuis bijwonen, zittend achter de laptop (livestream, waarover hieronder meer), of moesten op afstand afscheid nemen in een drive-through of staande langs de weg in een erehaag. Ten derde werden uitvaarten elders georganiseerd. Uitvaartondernemer Elbert Sluijmer vertelde me dat hij geregeld uitvaarten op de begraafplaats of in de natuur organiseerde. ${ }^{14}$

\section{Lichaam}

Een notie die vaak terugkomt in de verhalen en getuigenissen is het 'lichaam'. Ten eerste betreft dit het zieke, soms ook besmettelijke lichaam. Het lichaam dat men niet durft aan te raken, dat men op afstand houdt. Ten tweede gaat het bij deze notie om nabijheid, of beter: het gemis aan nabijheid. Nabijheid wordt veelal fysiek geuit: door een handdruk, een knuffel of omhelzing, maar vanwege de anderhalve-meter-maatregel was dergelijk fysiek contact niet mogelijk. Ritueelbegeleider Simone schrijft op de verhalenmuur van de Funeraire Academie:

"De anderhalve meter afstand houden. Ik vind het het lastigste als ik als ritueelbegeleider de familie ontvang in het crematorium. Ik zie en voel hun ongemakkelijkheid. Maar in deze tijden kan ik niet naar ze toestappen voor een handdruk of een tikje op de schouder."

Voor de condoleance na afloop van de uitvaart stelde uitvaartcoöperatie DELA alternatieve omgangsvormen voor, bijvoorbeeld door de rouwende te 
begroeten en te troosten door de hand op het hart te leggen. ${ }^{15}$ Het gebrek aan lichamelijk contact kan leiden tot meer stress en zelfs vastzittende rouw, aldus hoogleraar psychologie Geert Smid: “Ook voelen nabestaanden op de beperkt toegankelijke uitvaarten, maar ook daarna, minder steun. Alleen al een hand op de schouder kan verschil maken. We weten dat stress afneemt door lichamelijk contact." ${ }^{16}$ Crematoriumdirecteur Roel Stapper zegt in een interview dat juist waar lichamelijk contact ontbreekt, taal des te belangrijker wordt. ${ }^{17}$

\section{Rituele flexibiliteit}

De voorgaande noties gingen vooral over wat in de omgang met de dood en de doden in tijden van corona ontbreekt of niet kan: er is een gebrek aan tijd, aan plaats en aan lichamelijk contact. Een ander deel in mijn dossier laat juist zien wat er wel kan en gaat in op het groeiend aantal alternatieve rituelen of rituele elementen. Enerzijds hebben mensen moeite met de opgelegde beperkingen en het doorbreken van vaste patronen en tradities, anderzijds komen er nieuwe mogelijkheden op, nieuwe vrijheden die gewaardeerd en zelfs gekoesterd worden. Uit onderzoek in opdracht van uitvaartondernemer Monuta blijkt dat in 2020 twee derde van de nabestaanden belangrijke personen, voor henzelf of voor de overledene, niet konden uitnodigen bij de uitvaart. Toch blijkt dat, ondanks de beperkende maatregelen, $80 \%$ van de aanwezigen bij een uitvaart een goed gevoel had over hoe de uitvaart verlopen is. ${ }^{18}$

Opvallend veel verhalen in mijn dossier gaan over de intieme uitvaart. Het taalgebruik is hier belangrijk: uitvaartondernemers en ritueelbegeleiders benadrukken niet wat er niet is (er zijn minder mensen bij de uitvaart), maar wat er wel is: intimiteit. De uitvaart met minder aanwezigen, vaak een kring van vertrouwden en mensen die er 'echt toe doen', biedt vrijheid in vormgeving en aanpak en mogelijkheden tot improvisatie. Uitvaartondernemer Elbert Sluijmer zegt dat nabestaanden die bij een 'normale' uitvaart niet het woord durven te nemen, nu wel opstaan en hun herinneringen delen. ${ }^{19}$ Ritueelbegeleider Petra Stevens benadrukt juist de waarde van een klein, intiem afscheid, aldus een interview met haar in De Limburger:

Begrafenissen zijn noodgedwongen sober, in stilte, zonder opsmuk. Alsof het idee heerst: er is toch niet zo veel mogelijk, dus laat ook maar. En dat vereist een tegengeluid, meent Stevens. Samen met zes andere ritueelbegeleiders uit Nederlands- en Belgisch-Limburg is ze een campagne gestart om de voordelen van een kleine, intieme begrafenis onder de aandacht te brengen. "Afscheidsrituelen zijn belangrijk, juist nú. Je kunt nu dingen doen die in een groot gezelschap niet tot 
hun recht komen. Zo hebben we bij een uitvaart iedereen persoonlijk een kaarsje rond de baar laten zetten. Dertig lichtjes." ${ }^{20}$

Naast tips en voorbeelden van uitvaartondernemers en ritueelbegeleiders voor rituelen die 'corona proof' zijn, ${ }^{21}$ verschijnen er in de kranten en op social media verhalen over nieuwe en veranderende rituelen, overigens niet alleen in relatie tot uitvaarten en rouw, maar ook inzake bijvoorbeeld Koningsdag op 27 april en de Dodenherdenking op 4 mei. ${ }^{22}$ Op het online platform NieuwWij schreef Yvonne Brink over aanpassingen in de rituelen rondom de dood in islam en jodendom. Moslims mogen de rituele wassing van het dode lichaam op symbolische wijze doen of ervan afzien. In het jodendom wordt de sjiva, de zevendaagse rouwperiode waarbij vrienden en familie langskomen voor rouwbeklag, online gedaan via videobellen. ${ }^{23}$ Alternatieve rituelen rondom uitvaarten laten vooral solidariteit zien. Ik geef enkele voorbeelden. @TheRealYorin bericht op Twitter, 20 maart 2020 :

"Onze buurman is deze week totaal onverwacht overleden. Wegens de coronacrisis mogen er morgen maar 30 mensen (inclusief mensen van de Monuta) aanwezig zijn bij de uitvaart. Daarom met alle buren de buurt wat mooier gemaakt voor ze bij terugkomst van de condoleance vanavond." ${ }^{24}$

Bij de tweet staan foto's van lichtjes en kaarsen in de vorm van een groot hart. Bij een uitvaart in mijn eigen kennissenkring werd aan alle mensen die normaal gesproken bij de uitvaart aanwezig zouden zijn, gevraagd thuis een kaars te branden op het moment van de uitvaart en een foto hiervan te sturen naar de naaste familie. Predikant Joost Röselaers berichtte op 1 april 2020 op Twitter:

"Een bekende van mij overleed eergisteren (aan het Coronavirus). Aan al haar dierbaren is gevraagd om op hetzelfde moment naar haar favoriete uitvoering van 'Erbarme Dich' van Bach te luisteren. Verbondenheid in tijden van Corona."25

Tot slot @Koopmandick, op 2 april 2020: “Vandaag afscheid genomen van vriendin. Corona. Langs de weg gestaan met een rode roos. Diepe stilte. Raar, kaal en liefdevol." ${ }^{26}$

\section{Livestream}

Een direct gevolg van de beperkende maatregelen inzake het aantal aanwezigen bij een uitvaart is het toenemend gebruik van de mogelijkheden van 
livestream; ik wees hier al op bij de categorie 'plaats'. Veel crematoria boden al de mogelijkheid om de ceremonie in de aula op te nemen of via een livestream uit te zenden, corona heeft livestream tot een vanzelfsprekendheid gemaakt. Door deze ontwikkeling kunnen drie groepen van deelnemers aan de uitvaart onderscheiden worden. Ten eerste zijn er de direct nabestaanden en de beperkte groep genodigden die aanwezig zijn bij de uitvaart op locatie. Ten tweede zijn er de genodigden die via de rouwkaart of anderszins een link hebben ontvangen om de uitvaart via livestream bij te wonen. Bij deze groep gaat het om mensen uit het sociale netwerk van de overledene en/of de direct nabestaanden. Ten derde zijn er de ongenodigden: mensen die de link hebben zien staan in de rouwadvertentie in de krant of de link via internet hebben gevonden. Deze groep is diffuus van samenstelling: het kunnen mensen zijn uit het sociaal netwerk, maar ook onbekenden.

$\mathrm{Er}$ is veel te zeggen over het gebruik van livestream bij uitvaarten. Er dienen zich vragen aan betreffende participatie, mate van betrokkenheid, lichamelijkheid en zintuiglijkheid. Het aantal views van een livestream zegt weinig over de mate van betrokkenheid, want onbekend is of de 'kijker' de gehele uitvaart volgt, of slechts een deel; of hij kijkt tijdens het werk of met volle aandacht betrokken is. Megan van Kessel beschreef in het dagblad Het Parool, 28 november 2020, de dilemma's:

"Een begrafenis in coronatijd maakt de dood doodvermoeiend. Ik moest het doen met een link van een livestream waar ik met een wachtwoord toegang toe had. De dienst was onder werktijd en ik twijfelde of ik vrij moest vragen. Het voelde aanstellerig om niet te gaan werken. Ik vond het jammer dat corona het ritueel van mooi aankleden en de schoenen aandoen die je nooit draagt, wegnam. Het fysiek aanwezig zijn bij afscheid herinnert je aan de gunst te mogen leven. Het herenigt met verre familieleden en laat inzien hoe triviaal het gros van je problemen is. Coronamaatregelen gaven het drama geen kans op een van de weinige aangelegenheden dat drama er mag wezen. De weblink bood ook weinig ruimte voor empathie. 'Ik moet zo naar een begrafenis' heeft een ander effect dan 'Ik heb zo een begrafenis online'. (...) Wanneer je op iemands begrafenis bent, dan houd je je blik strak op de kist of een deurklink gericht. Dan zie je het verdriet van je medemens niet zo. Omdat je deels bezig bent om jezelf een houding te geven. Maar ook omdat je mensen niet gaat aangapen zoals ik dat vanachter mijn laptop deed. Als ik in de zaal had gezeten, had ik waarschijnlijk niet gehuild omdat het verdriet van anderen groter is. Nu mocht ik gewoon heel hard huilen om tante Tineke, ook al was ze mijn oudtante en had ik nooit bij haar gelogeerd." ${ }^{27}$ 
Uit dit lange citaat kunnen we concluderen dat sommige dingen gemist worden, onder andere het sociaal contact van een fysieke bijeenkomst. Maar er is ook een sterke mate van betrokkenheid en minder gêne om de emoties te tonen en de tranen de vrije loop te laten. Dat livestream en emotionele betrokkenheid elkaar niet in de weg zitten blijkt ook uit een tweet van Evelyne Verheggen, 30 mei 2020: "Begrafenis volgen via YouTube; het ontroert me meer dan ik dacht." ${ }^{28}$

Voor de eerste groep, de direct nabestaanden, is er soms een andere zorg. Een groot deel van het sociaal netwerk is niet fysiek aanwezig bij de uitvaart terwijl de direct nabestaanden hun verdriet en de verhalen over de overledene wel met een ruime kring van mensen willen delen. Hella van der Wijst schrijft over de al eerder genoemde twee zussen Baukje en Femke:

"Door alle beperkingen rondom de uitvaart hebben Baukje Femke en hun vader maar één doel: hoge kijkcijfers voor de livestream van de uitvaart. Dat heeft Toos verdiend. Niet wetend dat uiteindelijk honderden vrienden en familieleden het afscheid via een livestream volgen." (Wijst 2020, 147)

Zelf maakte ik mee hoe de eerste (offline) en tweede (online) groep met elkaar verbonden raken, ondanks de fysieke afstand. Tijdens de uitvaartplechtigheid van mijn schoonmoeder betrapte ik mij erop, toen ik moest spreken, dat ik me heel bewust was van de camera's. Door middel van een rood lampje kon je zien welke camera actief was en ik moest de neiging onderdrukken om me juist op die camera te richten. Ik hield mij voor dat het afscheidsritueel hier en nu diende te gebeuren, rondom de kist en met deze vijftig mensen. Toch was juist door die twee camera's de aanwezigheid van de grote kring van betrokkenen voelbaar: we waren hier met vijftig mensen, maar wat hier gebeurde was zichtbaar voor en werd meegemaakt door een grote kring van betrokkenen. Die betrokkenheid bleek toen mijn vrouw had gesproken over haar moeder. Onmiddellijk na haar toespraak ontving ze een appje van een nichtje: 'Mooi gesproken, wat ben jij sterk'. Natuurlijk zaten we tijdens de uitvaart niet op onze telefoons te kijken, maar het appje was te lezen op de smartwatch van mijn vrouw. Een paar minuten later volgde er een tweede appje van een goede vriend. De aanwezigheid van de grote kring van betrokkenen, hoewel op afstand, werd direct zichtbaar en voelbaar dankzij whatsapp.

\section{Tellen en herdenken}

Een laatste onderdeel in mijn dossier gaat in op hoe in de Nederlandse samenleving de doden genoemd en herdacht worden. In de eerste maanden van 
de coronacrisis werden elke avond in het NOS Achtuurjournaal de coronaaantallen van de dag gerapporteerd, waaronder het aantal doden door toedoen van corona. Tellen en herdenken speelde ook internationaal en lokaal een rol. Op rituele wijze werden de corona-doden genoemd en herdacht in de New York Times van 24 mei 2020 onder de titel: 'U.S. Death near 100,000, an Incalculable Loss'. In Tilburg werd in februari 2021 een herdenking georganiseerd waarbij 2874 kaarsjes werden aangestoken voor alle Brabanders die tot dan toe aan corona overleden waren. ${ }^{29}$

De COVID-19 pandemie, die we als een 'slow disaster' kunnen definiëren (Hoondert, Post, Klomp \& Barnard 2021), roept ook de vraag op naar een nationale herdenking en een nationaal monument. De discussie werd onder meer opgeroepen door de Groningse hoogleraar Christoph Jedan, die pleit voor een monument dat zowel offline als online dimensies heeft:

\footnotetext{
"Het moet niet alleen een tastbaar monument worden, maar er moet een online platform aan verbonden zijn, misschien met een QR-code. Op de website zou ruimte moeten zijn om individuele verhalen te delen, om verhalen van individuele en collectieve veerkracht te vertellen, om dankbaarheid te kunnen uiten naar zorgmedewerkers." ${ }^{3 \circ}$
}

Herdenkingen werden lokaal georganiseerd, ${ }^{31}$ op 6 oktober 2020 was er een 'Nationale dag van bezinning' en uiteindelijk kwam er een monument in Oisterwijk, dat op 8 september 2021 werd onthuld. Dit monument herdenkt niet alleen de coronaslachtoffers, maar is ook een eerbetoon aan de medewerkers in de zorg. ${ }^{32}$ De aandacht voor coronaslachtoffers op nationaal niveau in Nederland steekt enigszins mager af vergeleken met wat er in andere landen georganiseerd werd. Enkele voorbeelden: China hield in april 2020 drie minuten stilte voor de coronaslachtoffers. Spanje volgde in mei 2020 met tien dagen van nationale rouw. Italië riep 18 maart uit tot nationale herdenkingsdag. ${ }^{33}$ In London, UK, werd een National Covid Memorial Wall geplaatst. ${ }^{44}$

\section{Interpretatie van de gegevens uit het dossier}

Het afgelopen anderhalf jaar heeft de COVID-19 pandemie niet alleen mensenlevens en bestaansmiddelen bedreigd, maar ook ervaringen van sterven, herdenken en rouw veranderd. Tegelijkertijd zien we dat individuen en gemeenschappen met veel creatieve energie ingespeeld hebben op de beperkende maatregelen, waarbij nieuwe rituele praktijken en nieuwe toepassingen 
van technologie zijn ontstaan. De vraag is of deze veranderingen hebben geleid tot een nieuw cultureel patroon inzake de omgang met de dood. Zoals gezegd, deze vraag naar de 'death mentality' van het (post-)corona-tijdperk is (nog) niet of slechts met enige terughoudendheid te beantwoorden; zowel in Nederland als wereldwijd zitten we midden in deze complexe en nog steeds actuele situatie van de COVID-19 pandemie. Wel tekenen zich enkele ontwikkelingslijnen af, lijnen die we vanuit de geordende analyse van het dossier kunnen trekken. Ik vat deze lijnen samen in enkele trefwoorden die ik vervolgens toelicht. Op basis van deze ontwikkelingslijnen kom ik in de vijfde paragraaf tot een voorlopige conclusie inzake de veranderende omgang met de dood onder invloed van de COVID-19 pandemie.

1. Solidariteit: uit het dossier komt een sterk verlangen naar 'samen' en solidariteit naar voren. Er wordt geklapt voor zorgmedewerkers, er zijn lokale initiatieven om coronaslachtoffers te herdenken, netwerken rondom een overledene vinden nieuwe rituelen uit om hun respect en betrokkenheid te uiten (erehagen, vlag halfstok), nabestaanden bieden de mogelijkheid om de uitvaart door middel van een livestream bij te wonen. Hella van der Wijst gaf haar boek als titel De kracht van samen en die titel is, zo blijkt, goed gekozen.

2. Controle: tegelijkertijd is er ook het verlangen naar controle. Het steeds weer noemen van het aantal besmettingen, de cijfers inzake ziekenhuisopnamen en bezette IC-bedden en van het aantal coronadoden is niet bedoeld als een beschrijving van de werkelijkheid, maar een uiting van het verlangen naar controle over het virus. Ilja Pfeijffer beschrijft dit treffend in zijn coronadagboek:

"De aantallen besmettingen en dodelijke slachtoffers nemen af in Italië. We kunnen vraagtekens zetten bij alle cijfers, maar dat was eerder ook al zo en de onbetrouwbare cijfers van nu zijn onmiskenbaar lager dan de onbetrouwbare cijfers van weleer. (...) We zeiden dat we het virus moesten verslaan. Maar daar ging het allemaal niet om. Het ging om de controle. (...) Eén lullig, microscopisch klein virus sloeg onze illusie van controle aan diggelen. Dat verklaarde onze paniek en onze buitensporig hevige reactie. We probeerden de controle te herwinnen door alles wat we maar konden bedenken onder draconische controle te brengen. (...) Maar het virus is niet verslagen. Wanneer wij de controle over de grafieken opgeven, wil dat niet zeggen dat wij onze oude illusie van controle hervinden." (Pfeijffer 2020, 97-98) 
Het verlies van controle vraagt dat we 'iets' doen, vraagt om een ander houvast. De rituelen van solidariteit die ik onder nummer 1 noemde, kunnen we, in elk geval ten dele, begrijpen vanuit dit zoeken naar houvast. 35

3. Rituele flexibiliteit: de coronacrisis en de daarmee samenhangende beperkende maatregelen vragen een sterke mate van flexibiliteit van mensen. We zagen dit bijvoorbeeld bij gezinnen met schoolgaande kinderen, waar plotseling thuisonderwijs georganiseerd moest worden. ${ }^{36}$ Eenzelfde flexibiliteit zien we ten aanzien van rituelen rondom de dood. Ingesleten rituele patronen, zoals de ceremonie in de aula van het crematorium met toespraken, muziek en foto's uit het leven van de overledene, bleken en blijken ook aangepast te kunnen worden. Anders dan bijvoorbeeld in Italië werd er in Nederland niet gekozen voor een technische crematie zonder samenkomst, of een uiterst sobere plechtigheid bij het graf, maar in de meeste situaties toch voor een bijeenkomst, al was dat met minder personen dan gewenst. In het interview dat ik had met ritueelbegeleider Ger Thonen, vroeg ik hem of het uitvaartritueel onder invloed van de coronamaatregelen veranderd is. Zijn antwoord was een ferm 'nee': het ritueel is in de kern hetzelfde, de aanpak is wel anders. ${ }^{37}$

4. Personalisering: al enkele decennia is er de tendens van personalisering van de rituelen rondom de dood (Garces-Foley, 2006; Walter, 2020). Kathleen Garces-Foley typeert de gepersonaliseerde uitvaart als volgt:

\footnotetext{
"Personalized funerals have by now existed long enough that they have begun to develop their own 'tradition' in the sense of frequently used elements like the celebration of life theme, shared eulogy, and incorporation of pictures of the deceased." (Garces-Foley 2006, 224)
}

Deze 'traditie', zoals Garces-Foley beschrijft, heeft door de beperkende coronamaatregelen een enigszins ander karakter gekregen. Wat we zien, zijn nieuwe middelen waarmee de personalisering gestalte krijgt, zoals geïmproviseerde toespraken tijdens een uitvaart in kleine kring en het delen van herinneringen in een online videoconference.

5. Digitalisering: praktijken rondom de dood hebben in het afgelopen anderhalf jaar een online component gekregen. Dit is het meest duidelijk bij de livestream van uitvaarten, maar het blijkt ook uit bijvoorbeeld online zangsessies ${ }^{3}$ en online kerkdiensten. ${ }^{39}$ Online participatie aan rituelen wordt vaak als 'disembodied' omschreven, het fysieke contact ontbreekt (Hoondert \& Beek 2019). Dit wil echter niet zeggen, zo blijkt uit het onderzoek, dat het lichaam van degene die achter het scherm zit niet meedoet. Het lichaam is op 
een andere manier betrokken bij het ritueel, bijvoorbeeld door intens huilen, en er zijn wel degelijk mogelijkheden om het ontbreken van fysieke nabijheid te overbruggen door andere vormen van nabijheid, zoals het sturen van een whatsapp bericht.

\section{Conclusie}

Alvorens ik de (voorlopige) conclusie formuleer, is het goed in te gaan op de beperkingen van mijn onderzoek. Immers, de conclusie van mijn onderzoek wordt in sterke mate bepaald door de eigenheden van het dossier. Er zitten, hoe dan ook, blinde vlekken in het dossier en het is goed deze in kaart te brengen.

\section{Beperkingen}

Ik ben mij ervan bewust dat het dossier dat ik heb samengesteld in sterke mate gefocust is op rituelen, met name uitvaartrituelen en herdenkingen. Artikelen en verhalen over bijvoorbeeld de gevolgen van COVID-19 voor palliatieve zorg en verpleeghuiszorg ontbreken grotendeels in het dossier. Het rituele perspectief geeft weliswaar goed inzicht in de waarden die in een cultuur verankerd zijn, maar een bredere blik kan het culturele patroon inzake de omgang met de dood beter en vooral meer compleet in beeld brengen. Interdisciplinaire samenwerking is hiervoor nodig. Het DONE-netwerk (Dood Onderzoek Nederland), waarin onderzoekers die zich bezig houden met de dood (filosofen, antropologen, gezondheidswetenschappers enz.) verzameld zijn, biedt hiervoor een goed kader. ${ }^{\circ}$ Overigens ontbreken verhalen vanuit de verpleeghuizen niet helemaal in het dossier. Met name in het boek van Hella van der Wijst komt de impact van corona op de verpleeghuiszorg ter sprake, onder andere via de verhalen van Helma Huijsmans, teammanager woonzorgcentrum Simeonshof in Erp.

De samenstelling van het dossier waarop dit artikel gebaseerd is, is min of meer toevallig. Het bevat de bronnen die ik tegenkwam, ik heb niet systematisch Twitter of Facebook doorgenomen op berichten over corona en de dood. Een dergelijke Big Data-benadering leent zich goed voor het vinden van culturele patronen (Thelwall \& Thelwall 2020), maar ik ben niet getraind in dergelijke methoden. Ik probeer, op basis van 'kleine verhalen', veranderingen in de cultuur te begrijpen: een kwalitatieve, etnografische benadering (Blommaert 2013). 


\section{Conclusie}

In een prikkelend artikel in The Guardian, 20 april 2020, gaat Yuval Noah Harari in op de vraag of het coronavirus onze houding ten opzichte van de dood zal veranderen. Zijn antwoord is helder: nee. Volgens Harari blijven we vasthouden aan ons geloof in de wetenschap en blijven we proberen de dood onder controle te houden:

\footnotetext{
"We assume that humankind has the knowledge and tools necessary to curb such plagues, and if an infectious disease nevertheless gets out of control, it is due to human incompetence rather than divine anger. Covid-19 is no exception to this rule. The crisis is far from over, yet the blame game has already begun. Different countries accuse one another. Rival politicians throw responsibility from one to the other like a hand-grenade without a pin. Alongside outrage, there is also a tremendous amount of hope. Our heroes aren't the priests who bury the dead and excuse the calamity - our heroes are the medics who save lives. And our superheroes are those scientists in the laboratories." ${ }^{11}$
}

Wat Harari hier beschrijft past bij de ontwikkelingslijn die ik heb aangeduid met het kernwoord 'controle', maar naast of aanvullend op deze modernistische, seculiere houding ten opzichte van de dood, gekenmerkt door een groot vertrouwen in de wetenschap, zelfbeschikking en controle, zie ik ook een houding waarmee mensen de dood als het ware bezweren door zowel een rituele inbedding van de dood (rituele flexibiliteit) als een sterke mate van rituele solidariteit. De ritualisering kunnen we interpreteren in lijn met wat Ariès de 'getemde dood' heeft genoemd, al ontbreken hier de vanzelfsprekendheid van de dood als deel van het leven en de acceptatie van deze vanzelfsprekendheid door zowel de stervenden als de naasten. Beide zijn belangrijke kenmerken van deze 'death mentality'. Het zoeken naar nieuwe vormen van betrokkenheid en ritueel engagement interpreteer ik als een vorm van verzet of protest tegen zowel de dood door corona als de impact van het coronavirus. De intensivering van de ritualiteit - de ontwikkelingslijnen 1, 3, 4 en 5 wijzen daarop - functioneert als 'words against death': “a form of positive rhetoric of death, grounded in theologies and liturgies, through which death, bereavement and afterlife beliefs are formulated and expressed" (Davies 2017, 251). Douglas Davies, een autoriteit in Death Studies, gebruikt deze theorie om aan te geven dat mensen in hun reactie op dood en rouw woorden, muziek en rituelen gebruiken opdat de dood niet het laatste woord heeft (Davies 2005, 20). De erehaag die we op veel plaatsen hebben gezien, waarbij mensen die 
vanwege de beperkende maatregelen niet bij de uitvaart konden zijn toch hun betrokkenheid uitten, is hiervan een goed voorbeeld.

Samenvattend, welke culturele patronen inzake de omgang met de dood in tijden van corona in Nederland tekenen zich af? Enerzijds zien we dat mensen sterk blijven vertrouwen op de medische wetenschap en daarmee de dood door corona als een falen van de wetenschap zien (Ariès: denial of death). Anderzijds komt uit het explorerende onderzoek naar voren dat rituele praktijken zich dynamisch aanpassen aan de nieuwe context, opdat de dood niet het laatste woord heeft en nabestaanden niet alleen gelaten worden in hun verdriet. Mensen proberen op velerlei wijzen het stervensproces - van ziekbed tot rouw - in te bedden in een nieuwe of veranderende rituele context, een verschuiving in de omgang met de dood die zowel een sterke onderlinge solidariteit als protest tegen de dood uitdrukt. In lijn met de typeringen die Ariès gaf aan de verschillende culturele patronen inzake omgang met de dood zouden we dit 'our death' kunnen noemen. Zowel deze nieuwe omgang met de dood als de 'denial of death' zijn tegelijk aanwezig als culturele patronen die het denken en doen bepalen.

\section{Noten}

1 Zie https://coronadashboard.rijksoverheid.nl/landelijk/sterfte (geraadpleegd 1 september 2021).

2 Zie https://www.cbs.nl/nl-nl/nieuws/2021/33/1-op-de-8-sterfgevallen-in-2020-doorcovid-19 (geraadpleegd 1 september 2021).

3 Zie bijvoorbeeld https://www.ad.nl/buitenland/italiaans-bergamo-verandert-in-spook stad-elk-half-uur-een-begrafenis a921e480/ (geraadpleegd op 1 september 2021).

4 Zie bijvoorbeeld https://www.1limburg.nl/extra-koelruimte-bij-crematorium-wegenshoge-sterftecijfers (geraadpleegd op 1 september 2021).

5 Zie bijvoorbeeld het bericht op de website van EenVandaag, 16 april 2020: Jan Salden, Stille ramp in verpleeghuizen met honderden doden door coronavirus. 'Te lang niks gedaan met waarschuwing.' Zie: https://eenvandaag.avrotros.nl/item/stille-rampin-verpleeghuizen-met-honderden-doden-door-coronavirus-te-lang-niks-gedaanmet-waarsch/\#: :text=gedaan\%2 omet\%2 owaarschuwing'-,Stille\%2oramp\%2oin\% 2overpleeghuizen\%2 omet\%2 ohonderden\%2ododen\%2odoor\%2ocoronavirus \%3 A\% 2 o'Te,lang\% 2 oniks\% 2 ogedaan\% 2 omet\% 2 owaarschuwing'\&text=Ter wijl\%2ohet\%2oaantal\%2ocoronapati\%C3\%ABnten\%2oop,pati\%C3\%ABnten\%2o en\%2odie\%2ovan\%2ozichzelf (geraadpleegd op 14 oktober 2021). Ook Nieuwsuur besteedde aandacht aan de verpleeghuizen in de uitzending op 10 april 2020, zie: https://nos.nl/nieuwsuur/artikel/2330102-stille-ramp-in-verpleeghuis-de-ouderengaan-hier-een-voor-een-dood (geraadpleegd op 14 oktober 2021).

6 Ik dank student assistent Juliette Berndsen voor haar hulp bij het aanvullen en ordenen van het dossier inzake rituelen in relatie tot corona dat aan de basis ligt van dit artikel. Ik dank ook de twee (anonieme) reviewers voor hun waardevol en opbouwend commentaar bij een eerdere versie van dit artikel. 
7 Een internationale vergelijking van zowel veranderende rituelen onder invloed van de COVID-19 pandemie als de daarmee samenhangende veranderende omgang met de doodlaatikachterwegein ditartikel.Ziehiervoor het forum 'Ecologies of the dead and the living: Mourning out of place', http://tif.ssrc.org/category/exchanges/ecologies-of-deadliving/ (geraadpleegd op 12 oktober 2021).

8 Een opname van het webinar, de ervaringsverhalen en interviews zijn verzameld op een website, zie: https://www.totzover.nl/funeraire-academie/uitvaart-in-tijden-vancorona-overview/.

9 Coronacrisis: het belang van een goed afscheid (31 maart 2020), zie https://www.mo visie.nl/artikel/coronacrisis-belang-goed-afscheid (geraadpleegd op 4 augustus 2021).

10 Maarten van den Hurk, Steeds meer crematies op zondag en in de avonduren door vele sterfgevallen, Brabants Dagblad27maart2020,zie:https://www.bd.nl/uden-veghel-e-o/ steeds-meer-crematies-op-zondag-en-in-avonduren-door-vele-sterfgevallen a307 4297/?referrer=https\%3A\%2F\%2Fwww.google.nl\%2F (geraadpleegd op 4 augustus 2021).

11 Zie de reportage van Nieuwsuur: https://www.youtube.com/watch?v=FKILmFugzFc (geraadpleegd op 8 september 2020).

12 De documentaire is te zien via https://www.dela.nl/inspiratie/impact-van-de-coronauitbraak-op-dela-collegas. Zie ook wat Hella van der Wijst schrijft in haar boek over uitvaartonderneming Claassen in Veghel: Wijst, De kracht van samen: kroniek van een crisis, 136.

13 Zie onder meer: https://www.parool.nl/wereld/corona-in-brazilie-een-gevaar-voor-dehelewereld bfddea59/ (geraadpleegd op 4 augustus 2021).

14 Het interview is te beluisteren via https://www.totzover.nl/funeraire-academie/uitvaartin-tijden-van-corona-overview/interview-met-uitvaartondernemer-elbert-sluijmer/.

15 Zie https://www.dela.nl/over-dela/nieuws-en-media/20200309-informatie-over-uitvaar ten-en-coronavirus (geraadpleegd op 1 september 2021).

16 Annefleur van Wanroij, Verlies van een geliefde verwerken lastiger door corona, experts verwachten toename rouwstoornissen, 26 maart 2021, zie https://eenvandaag.avrotros. $\mathrm{nl} /$ item/verlies-van-een-geliefde-verwerken-lastiger-door-corona-experts-verwachtentoename-rouwstoornissen/ (geraadpleegd op 1 september 2021).

17 Het interview is te beluisteren via https://www.totzover.nl/funeraire-academie/uitvaartin-tijden-van-corona-overview/interview-met-crematoriumdirecteur-roel-stapper/.

18 A. Luiten, Uitvaarten in Coronatijd. Onderzoeksrapport (juli 2020), zie: https://branche bladuitvaartzorg.nl/wp-content/uploads/2020/09/20200727-Rapport-Uitvaarten-incoronatijd-NL-Eyes-1.pdf en het persbericht https://www.monuta.nl/over-monuta/ nieuws/onderzoek-een-derde-nederlanders-geconfronteerd-met-overlijden-coronatijd/ (geraadpleegd op 2 september 2021).

19 Zie noot 14.

20 R. Wiche, Flesje bier op de kist: ook een kleine en intieme uitvaart kan troost geven, De Limburger, 3 juni 2020.

21 Bijvoorbeeld Simone Snakenborg, Tips voor het afscheidsritueel op anderhalve meter, 17 juli 2020, https://www.rememberme.nl/inspiratie/blogs-van-simone-snakenborg/tips-voor-het-afscheidsritueel-op-anderhalve-meter-afstand (geraadpleegd op 2 september 2021). Zie ook het rapport van Arq Kenniscentrum Impact van Rampen en Crises: Verlies, rouwen en rituelen in coronatijd. Informatie voor nabestaanden, https://www.impact-kenniscentrum.nl/sites/default/files/domain-26/documents/ arqimpact_verlies_rouwen_en_rituelen_in_coronatijd_-_voor_nabestaanden_0204 2020-26-1585904438233669645.pdf (geraadpleegd op 2 september 2021).

22 Zie bijvoorbeeld de reportage over het 4 mei ritueel dat Hanke Amels met haar gezin uitvoerde: https://www.youtube.com/watch?v=86KoKdYpa9M. 
23 Yvonne Brink, Rituelen in de coronatijd, 20 juli 2020, https://www.nieuwwij.nl/opinie/ rituelen-in-de-coronatijd/ (geraadpleegd op 9 september 2021).

24 Twitter-account is opgeheven (geraadpleegd op 9 september 2021), foto van de tweet in mijn dossier.

25 https://twitter.com/Roselaers/status/1245253516421206017 (geraadpleegd op 9 september 2021).

26 https://twitter.com/koopmandick/status/1245674380404940800 (geraadpleegd op 9 september 2021).

27 Megan van Kessel, De link van de online begrafenis werkt niet. En nu?, Het Parool, 28 november 2020, https://www.parool.nl/columns-opinie/de-link-van-de-onlinebegrafenis-werkt-niet-en-nu b8c6e458/ (geraadpleegd op 10 september 2021).

28 https://twitter.com/EMFVerheggen/status/1266665472742821888 (geraadpleegd op 10 september 2021).

29 Marjanka Meeuwissen, 2874 brandende kaarsjes en woorden van hoop en troost: Brabantse coronaslachtoffers herdacht, Brabants Dagblad 27 februari 2021, https://www. omroepbrabant.nl/nieuws/3349949/2874-brandende-kaarsjes-en-woorden-van-hoopen-troost-brabantse-coronaslachtoffers-herdacht (geraadpleegd op 10 september 2021).

30 Toske Andreoli, "Er moet een nationaal monument voor Covid-19 slachtoffers komen", Science Guide 29 mei 2020, https://www.scienceguide.nl/2020/05/er-moet-een-natio naal-monument-voor-covid-19-slachtoffers-komen/ (geraadpleegd op 10 september 2021).

31 Zie https://nos.nl/artikel/2375678-mensen-bedenken-zelf-corona-herdenkingsplek ken-blijvende-herinnering (geraadpleegd op 10 september 2021).

32 Kim Spanjers, Coronacrisis herdacht met standbeeld: prinses Margriet en Hugo de Jonge bij onthulling, Brabants Dagblad 9 september 2021, https://www.omroep brabant.nl/nieuws/3859231/monument-voor-coronaslachtoffers-onthuld-in-oisterwijk (geraadpleegd op 10 september 2021).

33 https://www.thelocal.it/20210318/italy-marks-first-national-day-of-remembrance-forcovid-19-victims/ (geraadpleegd op 10 september 2021).

34 https://nationalcovidmemorialwall.org/enhttps://www.theguardian.com/world/2021/ jul/18/wall-of-love-the-incredible-story-behind-the-national-covid-memorial-led-bydonkeys (geraadpleegd op 10 september 2021).

35 Zie ook het essay 'In de greep van de dood' door enkele leden van DONE: https://www. totzover.nl/done/in-de-greep-van-de-dood/.

36 Zie bijvoorbeeld de resultaten van het onderzoek door de Hogeschool Utrecht: De impact van COVID-19 op gezinnen, https://www.hu.nl/onderzoek/onderzoek/de-impact-vancovid-19-op-gezinnen (geraadpleegd op 13 september 2021).

37 Het interview is te beluisteren via https://www.totzover.nl/funeraire-academie/uitvaart-in-tijden-van-corona-overview/interview-met-ritueelbegeleider-ger-thonen/.

38 Zie bijvoorbeeld koorantaine.nl: Samen zingen in tijden van afzondering.

39 Zie het themanummer van het tijdschrift Laetare over hybride liturgie: Laetare 37 (2021) 2.

40 Zie https://www.totzover.nl/done/.

41 Yuval Noah Harari, Will coronavirus change our attitudes to death? Quite the opposite, The Guardian, 20 april 2020, https:/www.theguardian.com/books/2020/ apr/20/yuval-noah-harari-will-coronavirus-change-our-attitudes-to-death-quite-theopposite (geraadpleegd op 10 september 2021). 


\section{Literatuur}

Ariès, P. (1974),

Western attitudes toward death: from the Middle Ages to the present, Baltimore [etc.]: Hopkins.

Ariès, P. (1983),

The hour of our death, Harmondsworth: Penguin.

Ariès, P. (1987),

Het uur van onze dood: duizend jaar sterven, begraven, rouwen en gedenken, Amsterdam:

Elsevier.

Becker, E. (1973),

The denial of death, New York: The Free Press.

Blommaert, J. (2013),

Ethnography, superdiversity and linguistic landscapes: chronicles of complexity, Bristol:

Multilingual Matters.

Davies, D. J. (2005),

A brief history of death, Malden, MA: Blackwell Pub.

Davies, D. J. (2017),

Death, ritual, and belief: the rhetoric of funerary rites, (Third edition), London:

Bloomsbury Academic.

Embsen, H. \& T. Overtoom (2007),

Hoe zou jij het willen? Persoonlijk afscheid nemen van je dierbare, Kampen: Ten Have.

Embsen, H. \& T. Overtoom (2017),

15 jaar innoveren. Het Moment 2002-2017, Hengelo: Het Moment.

Garces-Foley, K. (2006),

Death and religion in a changing world, Armonk, NY: M.E. Sharpe.

Heerma van Voss, D. (2020),

Coronakronieken, s.l.: s.n.

Hoondert, M. (2012),

De dag des oordeels: Het Dies irae, in: Bosman, F. (red.), Hemel en hel. Beelden van het hiernamaals in het westers christendom, Heeswijk: Abdij van Berne, 105-121.

Hoondert, M. \& S. van der Beek (2019),

Ritual in a digital society, Amsterdam/Groningen: Institute for Ritual and Liturgical Studies/Centre for Religion and Heritage.

Hoondert, M., P. Post, M. Klomp \& M. Barnard (eds.) (2021),

Handbook of Disaster Ritual. Multidisciplinary perspectives, cases and themes, Leuven: Peeters. 
Jacobsen, M. H. (2016),

“Spectacular Death" - Proposing a New Fifth Phase to Philippe Ariès's Admirable History of Death, in: Humanities, 5 (2).

Jacobsen, M. H. \& A. Petersen (2020),

The Return of Death in Times of Uncertainty-A Sketchy Diagnosis of Death in the Contemporary 'Corona Crisis', in: Social Sciences, 9, 1-17.

Jansen, J. \& D. Jansen (2020),

CoronA tot Z: 26 wetenschappers over COVID-19 en 26 columns van Dolf Jansen over ongeveer hetzelfde, Amsterdam: Fontaine Uitgevers.

Nijland, D., T. Overtoom \& M. Hoondert (2017),

Rituelen rond de dood, Heeswijk: Berne Media, Uitgeverij Abdij Van Berne.

Pfeijffer, I. L. (2020),

Quarantaine.Dagboek in tijden van besmetting, Amsterdam: Uitgeverij De Arbeiderspers. Saldaña, J. (2021),

The coding manual for qualitative researchers, (Fourth edition), London: SAGE Publications.

Thelwall, M. \& S. Thelwall (2020),

A thematic analysis of highly retweeted early COVID-19 tweets: consensus, information, dissent and lockdown life, in: Aslib Journal of Information Management, $72(6)$, 945-962.

Venbrux, E., M. Heessels \& S. Bolt (eds.) (2008),

Rituele creativiteit. Actuele veranderingen in de uitvaart- en rouwcultuur in Nederland, Zoetermeer: Meinema.

Venbrux, E., J. Peelen \& M. Altena (2009),

Going Dutch: Individualisation, secularisation and changes in death rites, in: Mortality, 14 (2), 97-101.

Walter, T. (2020),

Death in the modern world, London: Sage.

Wijst, H. van der (2020),

De kracht van samen: kroniek van een crisis, Heerenveen: Zilt.

Wojtkowiak, J. (2012),

"I'm dead, therefore I am". The postself and notions of immortality in contemporary Dutch society, Nijmegen: s.n. 